\title{
Penggunaan Media Visual dalam Pendidikan Jasmani dan Kesehatan
}

\author{
Dio Achmad Fajar \\ Jurusan Teknologi Pendidikan, Fakultas Ilmu Pendidikan, Universitas Negeri Malang \\ Email: dio.achmad.1801216@students.um.ac.id
}

\begin{abstract}
Abstrak
Media pembelajaran dapat membantu para guru dalam mengajar Pendidikan Jasmani dan Kesehatan. Media pembelajaran memungkinkan guru dalam mengeksplorasi materi pelajaran dan menyampaikannya dalam bentuk yang lebih komunikatif. Hal ini dapat membantu siswa dalam menyerap dan memahami subjek atau pesan dari guru dengan lebih baik. Media visual atau grafis adalah media yang berhubungan dengan visualisasi. Berbagai media visual yang dapat digunakan guru Pendidikan Jasmani dan Kesehatan antara lain adalah gambar, foto, sketsa, bagan, kartun, dan poster. Media yang cocok untuk Sekolah Menengah Pertama adalah gambar dan foto, namun demikian media grafis lainnya juga dapat digunakan. Sebelum menggunakan media visual atau grafik, guru Pendidikan Jasmani dan Kesehatan harus membuat penilaian kebutuhan belajar di Sekolah Menengah Pertama terlebih dahulu, dan memahami teknik pembelajaran dengan baik serta bagaimana dalam menggunakan media itu sendiri.
\end{abstract}

Kata kunci: Media Pembelajaran, Visualisasi, Media Visual

\section{The use of Visual Media in Physical Education and Health}

\author{
Dio Achmad Fajar \\ Department of Educational Technology, Faculty of Education, Universitas Negeri Malang \\ Email: dio.achmad.1801216@students.um.ac.id
}

\begin{abstract}
Learning media can help teachers in teaching Physical Education and Health. Learning media allow teachers to explore subject matter and present it in a more communicative form. This can help students absorb and understand the subject or message from the teacher better. Visual or graphic media is media that is related to visualization. Various visual media that can be used by Physical Education and Health teachers include drawings, photos, sketches, charts, cartoons, and posters. Media suitable for junior high schools are images and photos, however other graphic media can also be used. Before using visual or graphic media, Physical Education and Health teachers must first make an assessment of learning needs in junior high schools, and understand learning techniques well and how to use the media themselves.
\end{abstract}

Keywords: Learning Media, Visualization, Visual Media 


\section{PENDAHULUAN}

Sekolah Menengah Pertama (SMP) merupakan tingkat pendidikan dasar secara formal setelah melalui tingkat sekolah dasar. Pada umumnya siswa tingkat pendidikan ini berusia 12-15 tahun, dimana pada masa tersebut anak sudah bisa dikatakan sebagai remaja. Santrock mengatakan bahwa remaja adalah suatu masa transisi, yaitu perpindahan dari masa kanak-kanak menuju ke dalam masa dewasa (2011). Remaja memiliki peran yang penting dalam pencapaian cita-cita bangsa dimasa yang akan datang. Oleh karena itu, sangatlah penting adanya pendidikan pada masa remaja tersebut.

Permasalahan pendidikan pada jenjang Sekolah Menengah Pertama adalah kurangnya kreativitas guru dalam mengembangkan gaya pembelajarannya. Para guru cenderung hanya menggunakan metode ceramah saja, tanpa menampilkan sesuatu lainnya. Hal ini mengakibatkan siswa menjadi jenuh dan bosan dalam menangkap materi pelajaran yang diberikan oleh guru. Sehingga apa yang guru sampaikan kepada siswanya menjadi kurang maksimal.

Salah satu inovasi yang bisa digunakan guru dalam mengatasi permasalahan tersebut adalah dengan menggunakan bantuan dari media pembelajaran ketika kegiatan belajar dan pembelajaran. Menurut Azhar (2011), media pembelajaran adalah alat bantu pada proses belajar baik di dalam maupun diluar kelas. Lebih lanjut dijelaskan bahwa media pembelajaran merupakan komponen sumber belajar yang mengandung materi instruksional di lingkungan siswa yang dapat menstimulus siswa agar belajar. Adapun Rayanda Asyar (2012), berpendapat bahwa media pembelajar adalah segala hal yang dapat menyampaikan atau menyalurkan informasi dari sumber secara sistematis, sehingga tercipta lingkungan belajar yang kondusif dimana penerimanya dapat menjalankan proses belajar secara efisien dan efektif." Sedangkan menurut Arief Sadiman (2008) Media pembelajaran yaitu segala sesuatu yang bisa digunakan untuk menyampaikan pesan dari pengirim ke penerima pesan.

Penggunaan media pembelajaran kini semakin banyak, karena memang fungsinya yang dapat mempermudah guru dalam mengajar. Namun pemilihan media tersebut harus dipilih berdasarkan kegunaan dan fungsinya masing-masing. Salomon (1977), menyatakan bahwa efektivitas sebuah media bergantung pada kesesuaian dengan peserta didik atau pelajar, isi, dan tugas. Hal yang penting juga adalah media harus 
menitikberatkan pada sifat pembelajaran dalam ranah yang kompleks dan tidak terstruktur, hal ini sesuai dengan yang dikatakan R. Spiro, P. Feltovitch, dan R. Coulson (1990). Salah satu media pembelajaran yang terkenal adalah media visual. Media Visual (Daryanto, 1993) adalah alat peraga yang digunakan dalam proses belajar yang bisa dinikmati lewat panca-indera mata. Sedangkan Fathurrohman (2007) mengungkapkan bahwa media visual adalah media yang hanya mengandalkan indra penglihatan. Adapun Wibawa dan Mukti (1992) menjelaskan bahwa media visual dibedakan menjadi dua yaitu media visual diam dan media visual gerak. Media visual diam antara lain : foto, ilustrasi, flash card, gmbar pilihan dan potongan gambar, film bingkai, film rangkai, transparansi, proyektor tak tembus pandang, mikrofis, overhead proyektor, stereo proyektor, mikro proyektor dan tachitoscopes.

\section{KAJIAN LITERATUR}

Dalam kamus la Rousse Elementaire (1956) "Visual, elle est qui appartient a la vue", maksudnya visual adalah semua yang nampak atau terlihat. Dalam pembelajaran, visual adalah alat bantu pandang. Media visual memegang peran yang sangat penting dalam kegiatan belajar dan mengajar. Media visual sendiri dapat memperlancar pemahaman dan memperkuat memori. Visual dapat pula dimanfaatkan guna menumbuhkan minat siswa dan dapat memberikan hubungan antara isi materi pelajaran dengan apa yang ada di dunia nyata.

Agar menjadi efektif, visual sebaiknya ditempatkan pada konteks yang jelas dan siswa harus berinteraksi dengan gambar itu untuk meyakinkan terjadinya suatu proses informasi. Dengan demikian media visual dapat diartikan sebagai media pembelajaran yang bisa dilihat untuk mempercepat pemahaman dan memperkuat ingatan siswa akan materi pelajaran.

Media visual yang bergerak adalah media yang dapat menampilkan gambar atau bayangan yang dapat bergerak di layar bias, seperti; bias pada gambar-gambar yang ditampilkan oleh motion picture film dan loopfilm. Masing-masing media baik yang bergerak maupun yang tak bergerak dilihat penggunaannya tak lepas dari kelebihan dan keterbatasan yang ada, tergantung pada situasi dan kondisi pengoperasiannya.

Macam-macam media visual diantaranya adalahh media non proyeksi dan media proyeksi. Media non proyeksi disebut juga media pameran atau displayed media. Media 
visual non proyeksi dapat menerjemahkan ide abstrak menjadi lebih realistik. Memungkinkan pembelajaran berpindah dari tingkatan symbol-simbol verbal menuju tingkatan yang lebih nyata berdasarkan kerucut pengalaman Edgar Dale. Media visual nonproyeksi mudah digunakan karena tidak memerlukan banyak kelengkapan, relatif tidak mahal. Banyak hal dapat dijalankan dengan sedikit bahan bahkan tanpa biaya. Media non Proyeksi juga dapat pula digunakan dalam berbagai tingkatan pendidikan dan dalam berbagai disiplin ilmu. Hal lain yang bisa contohnya seperti digunakan dalam hal menstimulasi ekspresi kreatif, seperti penceritaan atau penulisan cerita dan penyusunan puisi. Pendidik dan dosen dapat menggunakan semua jenis media non proyeksi dalam tes dan evaluasi . Media ini akurat dan teliti dalam mengidentifikasi manusia, tempat, atau benda-benda lainnya. Beberapa media visual non proyeksi dapat pula digunakan sebagai kebutuhan kelompok kecil maupun kelompok yang besar. Jenis ini juga memungkinkan untuk memperbesar gambar-gambar hasil fotografi, tetapi itu merupakan proses yang relatif mahal. Sebuah foto dokumentasi dapat memperlihatkan gambar lebih besar dalam sebuah kelompok.

Beberapa media visual non proyeksi membutuhkan perhatian khusus, karena gambar simbolik dilengkapi gambar yang representatif, media harus menggambarkan ruangan pengamatan untuk menghilangkan salah tafsir dari makna yang terkandung. Ahli psikologi menemukan bahwa orang akan mengikuti untuk menggambarkan keinginan mereka, rasa takut dan konsepsi sebelumnya dalam gambaran atau pesan verbal yang kurang jelas.

Media non proyeksi memiliki fungsi untuk menyalurkan pesan dari pemberi ke penerima pesan (dari pendidik kepada siswa). Pesan yang dituangkan dalam bentuk tulisan, huruf-huruf, gambar-gambar, serta dengan simbol-simbol. Kelebihan dari media non proyeksi adalah dapat menarik perhatian siswa dalam proses belajar mengajar dan mempermudah menangkap materi yang diberikan, mudah didapat, dan bentuknya bervariasi. Sedangkan kekurangannya adalah tidak adanya audio, lambat, kurang praktis, dll.

Prinsip- prinsip media non proyeksi meliputi: teks dibaca secara linear, menampilkan komunikasi secara satu arah dan reseptif, ditampilkan secara statis atau diam, pengembangannya sangat tergantung kepada prinsip-prinsip pembahasan, berorientasi atau berpusat pada siswa. 
Adapun macam-macam media non proyeksi diantaranya adalah; (1) Media Realia, menurut Rusman (2005) Media realia yaitu semua media nyata didalam ruang kelas, tetapi dapat digunakan sebagai sesuatu kegiatan observasi pada lingkungannya. Udin S.W (Patty, 2007) menambahkan media realia adalah alat bantu visual dalam pembelajaran yang berfungsi memberikan pengalaman langsung kepada peserta didik. Sedangkan Pujita (2008), mengungkapkan bahwa ciri media realia adalah benda asli benda yang dalam keadaan utuh, dapat dioperasikan, hidup, dalam ukuran yang sebenarnya dan dapat dikenali sebagaimana wujud aslinya. Media Realia meliputi; (a) Model. Agus Suprijono (2011) berpendapat bahwa model adalah pola yang digunakan sebagai pedoman dalam merencanakan pembelajaran di kelompok maupun tutorial. Dalam konteks visual, model merupakan benda tiruan dalam wujud tiga dimensi yang merupakan representasi atau pengganti dari benda yang sesungguhnya. Misalnya untuk mempelajari sistem gerak, pencernaan, pernafasan, peredaran darah, sistem ekskresi, dan syaraf pada hewan. Kemudian (b) Media grafis. Sadiman (2009), Nurfaedah (2019) mengungkapkan bahwa media grafis termasuk media visual. Hal tersebut sejalan dengan yang diungkapkan Sanjaya (2009) bahwa media grafis adalah media yang dapat mengkomunikasikan data dan fakta, gagasan serta ide-ide melalui gambar dan kata-kata. Hamzah \& Nina (2010) menambahkan bahwa media grafis adalah media yang digolongkan sebagai media visual non proyeksi, yang artinya mudah digunakan karena tidak membutuhkan peralatan serta relatif terjangkau. Fungsi dari media grafis adalah menarik perhatian, memperjelas sajian pelajaran, dan mengilustrasikan suatu fakta atau konsep melalui sebuah simbol visual Macam-macam media grafis; (1) Gambar/Foto. Azhar Arsyad (1995), mengatakan bahwa gambar adalah berbagai peristiwa atau kejadian, objek yang dituangkan dalam bentuk gambar-gambar, garis, katakata, simbolsimbol, maupun gambaran. (2) Sketsa. Menurut But Muchtar (1987) pengertian sketsa dalam seni sketsa adalah ungkapan yang memiliki fungsi sebagai media dalam proses kreativitas tapi sekaligus sebagai sebuah karya. Adapun Meyers (1969) menyatakan bahwa sketsa adalah gambar catatan yang membedakannya dengan gambar karya lengkap serta juga gambar karya studi. Dalam karya studi, gambar merupakan eksplorasi teknis atau bentuk untuk penyelesaian lukisan, patung, dan lain-lain. (3) Diagram. Menurut Sutartini Fransiska (2001) Diagram adalah gambar atau grafik yang berisi keterangan tentang hal-hal tertentu yang menunjukkan hubungan antara besaran- 
besaran suatu variabel. Sedangkan Rhonda Abrams (2001) mengatakan bahwa diagram merupakan cara yang baik untuk mengomunikasikan informasi penting atau yang mengesankan dalam bentuk visual. (4) Bagan. Menurut Handoko (2013) Bagan adalah sebuah mekanisme formal contohnya seperti pola organisasi sekolah yang membagibagi tugas dari anggota organisasi yang ada. Sedangkan Gibson, dkk (2002) menemukakan bahwa bagan adalah sebuah pola formal pengelompokan orang atau yang lainnya yang ditunjuk dalam bagan organisasi tersebut. Fungsi dari bagan adalah menyajikan ide atau konsep yang sulit sehingga lebih mudah dicerna siswa. Pada suatu bagan sering dijumpai bentuk grafis yang lain, seperti: gambar, diagram, kartun, ataupun lambang verbal. (5) Grafik. Wai \& Kaicher (1976) menyatakan bahwa pengertian grafik adalah gambar yang terdiri dari titik-titik dan garis yang menghubungkan titik-titik tersebut. Lalu Harper (1988) menyatakan bahwa pengertian grafik adalah alat untuk menampilkan data berupa garis atau kurva yang menghubungkan satu variabel dengan variabel yang lain. Lalu ada juga Wilson (1998) yang menyatakan bahwa grafik ialah garis horizontal dan vertikal yang menghubungkan antara dua titik.

Sedangkan media proyeksi adalah media visual yang hanya dapat digunakan dengan bantuan proyektor (Masriadi, 2019). Berbeda dengan media non proyeksi, media ini harus menggunakan alat elektronik untuk menampilkan pesan atau informasi. Media proyeksi dibagi menjadi dua macam jenis, yaitu media proyeksi diam dan media media proyeksi bergerak. Berikut ini macam-macam dari media proyeksi diam; (1) Overhead Proyector (OHP). Dalam daftar kelompok peralatan proyeksi, OHP merupakan peralatan yang paling sederhana. Alasannya ialah peralatan ini hanya menggunakan sistem optik (lensa-lensa) dan elektrik (kipas pendingin dan lampu proyektor) saja. OHP sendiri berfungsi untuk memproyeksikan (menyajikan) transparansi, dan transparansi yang diproyeksikan berwujud visual baik berupa huruf, lambang, gambar, grafik, atau gabungannya pada lembaran bahan tembus pandang yang dipersiapkan untuk diproyeksikan ke sebuah layar/dinding melalui sebuah proyektor. Kemampuan proyektor memperbesar gambar membuat media ini brguna untuk menyajikan informasi pada kelompok yang besar dan pada semua jenjang. OHP dirancang untuk dapat digunakan di depan kelas sehingga guru dapat selalu berhadapan atau menatap siswanya. 
Beberapa kelebihan dari OHP adalah sebagai berikut; (a) Gambar yang diproyeksikan lebih jelas dibanding gambar di papan. (b) Dapat digunakan untuk menyajikan pesan dalam semua ukuran ruangan kelas. (c) Menarik, karena memungkinkan penyaji yang variatif dan disertai dengan warna -warni yang menarik. (d) Tatap muka dengan wajah siswa selalu terjaga dan memungkinkan siswa untuk mencatat hal -hal yang penting. (e) Tidak memerlukan operator secara khusus dan tidak pula memerlukan penggelapan ruangan. (f) Dapat menyajikan pesan yang banyak dalam waktu yang relatif singkat. (g) Kertas transparan bisa digunakan secara berulang ulang.

Namun, selain memiliki kelebihan seperti di atas, OHP atau OHT juga memiliki kekurangan, yaitu sebagai berikut; (a) Memerlukan perencanaan yang matang dalam pembuatan dan penyajiannya. (b) OHP dan kertas transpaaran memerlukan bagian yang tidak terpisahkan, karena gambar dan kertas biasa tidak bisa diproyeksikan melalui OHP,tapi harus melalui kertas transparan atau OHT. (c) Urutan kertas transparan sering kacau, karena berdiri sendiri dan tidak ada nomor urutannya sehingga membingungkan pendidik yang menyajikannya.

Kedua (2) Slide. Slide (film bingkai) merupakan suatu film transparansi yang memiliki ukuran $35 \mathrm{~mm}$ dengan bingkai 2 × 2 inci. Bingkai tersebut terbuat dari karton atau plastik. Film bingkai diproyeksikan melalui slide projector. Jumlah film bingkai yang akan ditayangkan untuk suatu program tergantung kepada tujuan yang ingin dicapai. Dengan demikian, lama penayangan atau panjangnya program sangat bervariasi. Slide ini hanya menampilkan satu gambar saja, teknisnya juga satu persatu. Ada juga slide yang berupa sound slide atau rupa rungu. Sound slide berupa hasil perpaduan antara gambar diam dengan suara (sound).

Setidaknya, ada empat kelebihan dari media slide, yaitu; (a) Membantu menimbulkan pengertian dan ingatan yang kuat pada pesan yang di sampaikan, (b) Menstimulus minat dan perhatian siswa dengan warna serta gambar yang konkrit, (c) Program slide mudah disesuaikan sesuai dengan kebutuhan, karena filmnya yang terpisah-pisah, (d) Penyimpanannya mudah kerena ukurannya kecil. Adapun kekurangannya adalah; Slide ini memerlukan penggelapan ruangan untuk memproyeksikannya serta pembuatannya memerlukan waktu yang cukup lama jika 
program yang di buatnya cukup panjang, memerlukan biaya yang cukup besar, hanya dapat menyajikan gambar diam saja.

Ketiga (3) yaitu Filmstrip (Film Rangkai). Filmstrip disebut juga film slide, stripfilm, dan still film yang arti dan fungsinya sama. Berbeda dengan slide, gambar (frame) pada film rangkai berurutan merupakan satu kesatuan. Ukuran filmnya sama dengan film bingkai, yaitu $35 \mathrm{~mm}$. Jumlah gambar satu rol film rangkai antara 50 sampai dengan 75 gambar dengan panjang lebih kurang 100 sampai dengan $130 \mathrm{~cm}$, tergantung pada isi film itu. Sebagaimana film bingkai, film rangkai bisa tanpa suara bisa pula dengan suara. Suara yang menyertai film rangkai itu dimaksudkan untuk menjelaskan isi. Selain dengan suara yang direkam, penjelasan dapat disampaikan dalam bentuk buku pedoman atau narasi tulis di bawah gambar yang dibacakan oleh guru atau dibaca sendiri oleh siswa.

Filmstrip mempunyai 3 jenis, yaitu (a) Opaque Projector (Proyektor Tak Tembus Pandang). Proyektor tak tembus pandang adalah alat untuk memproyeksikan bahan bukan transparan, tetapi bahan-bahan tidak tembus pandang (opaque). Benda-benda tersebut adalah benda datar, tiga dimensi seperti mata uang, model, serta warna dan anyaman dapat diproyeksikan. Kelebihan proyeksi tak tembus pandang sebagai media pendidikan adalah bahan cetaknya pada buku, majalah, foto grafis, ataupun peta dapat diproyeksikan secara langsung tanpa dipindahkan ke dalam transparan terlebih dahulu. (b) Microfis. Mikrofis adalah lembaran film transparan terdiri dari lambang-lambang visual (grafis maupun verbal) yang diperecil sedemikian rupa sehingga tak dapat dibaca dengan mata telanjang. Ukurannya bermacamm-acam, mulai dari $3 \times 5$ inci, $6 \times 8$ inci atau $4 \times 6$ inci. Keuntungan terbesar dari alat ini adalah dapat menghemat ruangan. Halaman cetak yang besar dapat dirangkum kedalam bentuk film yang baik dengan perbandingan 1:12, dimana selanjutnya dapat dikembalikan lagi ke bentuk semula dengan memproyeksikan ke layar. (c) Film/Video. Film atau gambar hidup merupakan kumpulan gambar dalam frame, yang mana frame demi frame tersebut diproyesikan melalui lensa proyektor secara mekanis, sehingga pada layar gambar itu memberikan kesan terlihat hidup. Film bergerak cepat dan bergantian sehingga memberikan visual yang kontinu. Sama halnya dengan film, video dapat menggambarkan suatu objek yang bergerak bersamasama dengan suara alamiah atau suara yang sesuai. Kemampuan film dan video melukiskan gambar hidup dan suara memberinya daya tarik tersendiri. Kedua 
jenis ini pada umumnya digunakan untuk tujuan-tujuan hiburan, dokumentasi, dan pendidikan. Keduanya dapat menyajikan informasi, memaparkan proses, menjelaskan konsep-konsep yang rumit, mengajarkan ketrampilan, menyingkat atau juga memperpanjang waktu dan mempengaruhi sikap. Penggunaan media proyeksi ini dapat menvisualkan pesan yang menarik (tergantung dari variasi yang digunakan guru atau dosen), praktis dan dapat dipergunakan secara berulang-ulang. Namun dalam pembuatan slide atau filmstrip dibutuhkan perencanaan yang matang dan dibutuhkan keterampilan melukiskan pesan yang ringkas dan jelas, dan menuntut penataan ruangan yang baik. Saat ini alat-alat tersebut semakin jarang digunakan tertutama setelah berkembangnya komputer yang mampu memproyeksikan pesan dengan lebih baik dan lebih bervariatif. Penggunaan media grafis dan proyeksi pada dasarnya menvisualkan fakta, gagasan, kejadian, peristiwa dalam bentuk tiruan keadaan sebenarnya untuk dibahas di dalam kelas. Di lain pihak guru dan siswa dapat mempelajari keadaan sebenarnya di luar kelas dengan menghadapkan kepada siswa lingkungan yang aktual untuk dipelajari. Jika memungkinkan cara ini lebih bermakna karena para siswa dihadapkan dengan peristiwa dan keadaan yang sebenarnya secara alami, sehingga lebih nyata, lebih faktual dan kebenarannya dapat dipertanggungjawabkan.

Sedangkan macam-macam media proyeksi gerak antara lain adalah; (1) LCD (Liquid Crystal Display). LCD merupakan salah satu alat optik dan elektronik. Sistem optiknya yang efisien mampu menghasilkan cahaya yang terang tanpa menggelapkan lampu ruangan, sehingga dapat memproyeksikan tulisan, gambar, atau gabungan dari tulisan dan gambar yang dapat dipancarkan dengan baik ke layar. (Hujair. 2011). (2) Film Gelang. Film gelang atau film loop dapat diartikan sebagai jenis media yang terdiri dari film berukuran $8 \mathrm{~mm}$ dan $16 \mathrm{~mm}$ yang ujung-ujungnya saling bersambungan sehingga film ini akan bermain secara berulang terus jika tidak dimatikan. (3) Televisi. Televisi ialah alat penangkap siaran bergambar, yang berupa audio visual dan penyiaran videonya secara broadcasting. Istilah televisi berasal dari pengambilan bahasa Yunani, yakni tele yang berarti jauh dan vision yang berarti melihat, yang secara harfiah apabila disambungkan bermakna "melihat jauh", sebab pemirsa berada jauh dari studio tv (Ilham Z, 2010). Sedangkan menurut Adi Badjuri (2010) televisi ialah media pandang sekaligus media pendengar (audio-visual), yg dimana orang tak hanya memandang gambar yang ditayangkan televisi, tetapi sekaligus mendengar atau mencerna narasi dari 
gambar itu. (4) Komputer. Wimatra, dkk (2008) mengatakan bahwa yang dimaksud dengan komputer ialah suatu sistem perangkat elektronik yang memilki tujuan untuk melakukan proses pengolahan data, yang kemudian hal tersebut diolah agar dapat menghasilkan suatu informasi yang berguna. Lalu Susanto (2003) juga mengatakan yang dimaksud komputer adalah suatu alat elektronik yang mampu melakukan multitasking seperti menerima input data, memproses input data sesuai dengan programnya, menyimpan perintah-perintah dan hasil pengolahan, serta menyediakan output data dalam bentuk informasi.

Pendidikan Jasmani dan Kesehatan merupakan salah satu pendidikan yang ada di Indonesia dengan mencakup aspek secara keseluruhan baik itu afektif, kognitif, dan psikomotorik, tetapi di balik itu semua ada masalah besar yang akan terus mendatangi kualitas pembelajaran pendidikan jasmani dan kesehatan jika tidak di cari solusi yang tepat untuk memperbaiki mutu dan kualitas pendidikan jasmani da kesehatan tersebut.

Pendidikan jasmani dan kesehatan di Indonesia saat ini dalam keadaan yang memperihatinkan karena belum efektifnya pembelajaran pendidikan jasmani dan kesehatan di sekolah, hal tersebut diakibatkan rendahnya pengetahuan akan pentingnya pembelajaran pendidikan jasmani dan kesehatan yang tidak disosialisasikan sejak dini. Padahal pendidikan adalah sebuah hal yang paling intim untuk melahirkan sumber daya manusia yang unggul yang nantinya akan membawa negara ini ke arah yang lebih baik. Jika pendidikan jasmani dan kesehatan diberikan sesuai dengan porsinya, tidak menutup kemungkinan akan tercipta bibit-bibit yang unggul dari pendidikan jasmani dan kesehatan yang bisa bersaing di kancah internasional. Karena atlet yang hebat berawal dari pendidikan jasmani dan kesehatan yang diberikan oleh guru yang profesional.

Selanjutnya, faktor-faktor yang menyebabkan rendahnya mutu dan kualitas pendidikan jasmani dan kesehatan di Indonesia yaitu; (1) Saat ini masih banyaknya sarana dan prasarana pendidikan di indonesia yang masih dibawah kategori layak, banyak sekolah tidak memiliki lapangan, alat, bahkan buku ajar untuk memperluas wawasan siswa. Tidak hanya sekolah yang berada di desa, tetapi sekolah yang berada di tengah-tengah ibu kota pun tidak memiliki lapangan masih sering dijumpai. Begitu miris pendidikan jasmani dan kesehatan di Indonesia jika dilihat secara keseluruhan. (2) Rendahnya kualitas guru pendidikan jasmani dan kesehatan di sekolah yang melahirkan ketidakmampuan mereka dalam melaksanakan profesinya secara profesional. Mereka 
belum berhasil melaksanakan tanggung jawab untuk mendidik siswa secara sistematik melalui program pendidikan jasmani dan kesehatan yang semestinya dapat mengembangkan kemampuan dan keterampilan anak secara menyeluruh. Guru pendidikan jasmani dan kesehatan yang masih sering menggunakan metode baku dalam pembelajaran membuat siswa tidak tertarik dan merasa bosan. Seharusnya guru pendidikan jasmani dan kesehatan mengubah pola pembelajarannya yang monoton agar tidak terpaku pada suatu pola yang membuat siswa merasa jenuh. Sehingga disinilah peran guru dituntut sekreatif mungkin dalam membuat pembelajaran yang menyenangkan. Walaupun guru dan pengajar bukan satu-satunya faktor penentu keberhasilan pendidikan jasmani dan kesehatan, tetapi pengajaran yang profesional merupakan titik sentral pendidikan. (3) Kurangnya pemerataan kesempatan pendidikan dan biaya pendidikan yang terlalu mahal bagi siswa yang tidak mampu dirasa tidak adil, sehingga sumber daya manusia yang tercipta rendah. Disinilah peran pemerintah dipertanyakan, seharusnya pemerintah berkewajiban untuk menjamin setiap warganya memperoleh pendidikan yang sama dan menjamin akses masyarakat bawah untuk mendapatkan pendidikan yang bermutu.

Selain dari 3 poin utama tersebut, salah satu hal yang juga berpengaruh besar terhadap kurang maksimalnya kualitas pendidikan jasmani dan kesehatan di sekolah adalah tidak digunakannya media pembelajaran (media visual) dalam pengajaran pendidikan jasmani dan kesehatan secara baik. Padahal peran dari media visual ini bisa dikatakan besar, mengingat pendidikan jasmani dan kesehatan merupakan mata pelajaran yang sebagian besar menggunakan kegiatan praktik. Contohnya seperti materi pelajaran permainan bola besar/kecil, bela diri, kebugaran jasmani, dll. Siswa akan kebingungan apabila menerima penjelasan dari guru saja tanpa ilustrasinya. Maka dari itu disini peran media visual dibutuhkan, melalui penggunaan media visual, siswa nantinya akan ditunjukkan gambar-gambar bagaimana cara mempraktikkan gerakan bermain sepak bola misalya, atau gerakan-gerakan bela diri, senam dll. Gambar yang ditampilkan tentu saja adalah gambar yang sesuai dan relevan dengan materi pelajaran yang diajarakan. 


\section{KESIMPULAN}

Media visual adalah salah satu dari jenis media media pembelajaran yang mempunyai ciri-ciri menggunakan gambar dalam penyajiannya. Media visual digunakan sebagai gambar ilustrasi pada penjelasan suatu artikel yang dirasa sulit dipahami artiannya secara lisan/tulisan. Melalui gambar yang ditampilkan, hal tersebut dapat memberikan pemahaman melalui simbol yang diterjemahkan sendiri oleh pembaca.

Dalam pemanfaatannya di dunia pendidikan, media visual sering digunakan pada materi pelajaran yang membutuhkan ilustrasi tambahan agar mempermudah siswa dalam memahami materi yang diajarkan oleh guru, contohnya pada materi pelajaran pendidikan jasmani dan kesehatan. Melalui pemanfaatan media visual ini, siswa dapat lebih muda melihat bagaimana cara untuk mempraktikkan ilmu olahraga seperti teknik bermain sepak bola, bermain bola basket, atau hal lain seperti teknik berenang yang baik. Gambar-gambar yang disajikan tentu saja adalah gambar yang mudah dilihat, serta dapat menjadikan siswa mudah dalam mencontoh atau menerapkan dan mempraktikkannya dalam pembelajaran.

\section{DAFTAR REFERENSI}

Ade Chandra, R. D. Pengembangan Media Visual Kartu Angka Efektif Untuk Mengenalkan Huruf Vokal a, I, U, E, O Pada Anak Usia Dini 3-4 Tahun Paud Labschool Jember. J. INDRIA (Jurnal Ilm. Pendidik. Prasekolah dan Sekol. Awal) 2, 62-71 (2017).

Almasitoh, U. H. Stres Kerja Ditinjau Dari Konflik Peran Ganda Dan Dukungan Sosial Pada Perawat. Psikoislamika J. Psikol. dan Psikol. Islam 8, 63-82 (2011).

Chotijah, S., Maftukhin, A. \& Nurhidayati. Pengaruh Model Pembelajaran Tari Bambu Terhadap Kemampuan berpikir kritis dan Hasil Belajar Fisika Siswa Kelas X SMA N 1 Sapuran TA 2013/2014. J. Radiasi 5, 71-74 (2014).

Ferry Christian. Mendiagnosis Kerusakan Perangkat Keras Motherboard Pada Personal Computer Menggunakan Sistem Pakar. (2008).

Hariyani, N. Televisi Lokal Dalam Perencanaan Strategi Kreatif Program Berbasis 'Lokalitas' Sebagai Wujud Eksistensi Media. J. Sos. 14, 30-31 (2013).

Handoko, D. S., Rusda, D. \& Ali, U. D. Sistem Informasi Manajemen Pembiayaan Konsumen Pada Pt . Commerce Finance Berbasis Desktop. 1-6.

Ma, Z. A. Perubahan gebyok sebagai kajian budaya masyarakat kudus. Disprotek 5, 1-19 (2014).

Masnunah, M. Media Realia dan Media Maya Dalam Pembelajaran Agama Islam Di Sd. Wahana Sekol. Dasar 26, 51-55 (2018).

Masriadi, M. (2019). Perancangan Multimedia Pembelajaran Mesin Mobil Menggunakan Software Adobe Flash untuk Siswa Sekolah Menengah Kejuruan. Indonesian Journal of Instructional Media and Model, l(1).

Mega, N. L. G., Dewi, P., Asri, I. G. A. A. S. \& Wiyasa, I. K. N. MODEL PEMBELAJARAN TAKE AND GIVE BERBANTUAN MEDIA GRAFIS TERHADAP HASIL BELAJAR PKn SD. Mimb. PGSD Univ. Pendidik. Ganesha 2, 2014 (2014). 
Meriani, N. K., Darsana, I. W. \& Suardika, I. W. R. PENGARUH MODEL BRAIN BASED LEARNING BERBANTUAN MEDIA GRAFIS TERHADAP HASIL BELAJAR IPS SISWA KELAS V SD NEGERI GUGUS LETDA KAJENG Jurusan Pendidikan Guru Sekolah Dasar, FIP Universitas Pendidikan Ganesha. (2014).

Muhson, A. Pengembangan Media Pembelajaran Berbasis Teknologi Informasi. J. Pendidik. Akunt. Indones. 8, (2010).

Nurfaedah, N. (2019). Keefektifan Media Audio Visual dalam Meningkatkan Kompetensi Siswa Sekolah Menengah Pertama dalam Menulis Puisi. Indonesian Journal of Instructional Media and Model, l(1).

Nuryati. Pendidikan Anak Usia Dini. J. Golden Age Univ. Hamzanwadi 01, 82-89 (2018)

Pahliwandari, R. Penerapan Teori Pembelajaran Kognitif dalam Pembelajaran Pendidikan Jasmani dan Kesehatan. J. Pendidik. Olahraga 5, 154-164 (2016)Purwanto, C. Analisis kesulitan mahasiswa dalam memahami grafik pada perkuliahan fisika dasar jurusan fisika universitas negeri semarang (The analysis of student difficulties in understanding the graph in basic physics course in physics department). 73 (2016).

R. Arizal Firmansyah dan Umi Khumaidah. Teacher-Centered Learning Melalui Process Oriented Guided Inquiry Learning. J. Tadris Kim. 66, 130-144 (2017).

S, M. I., Mesran, Siregar, D. \& Suginam. Rancangan Pendukung Keputusan Pemilihan Televisi Berlangganan Menerapkan Metode Analytical Hierarchy Process(Ahp). Media Inform. Budidarma 1, 42-48 (2017).Siswana, L., Halidjah, S., Studi, P., Guru, P. \& Dasar, S. PENGARUH MEDIA VISUAL TERHADAP KETERAMPILAN MENULIS. 1-9.

Setyaningsih, C. A., Rozanti, N., Andini, G. \& Hidayat, T. Keefektivan Penggunaan Media Realia Terhadap Hasil Belajar IPA di Sekolah Dasar. J. Muara Pendidik. 4, 321-331 (2019).

Tutantri, E., Tarigan, B., Dasar, S. \& Percontohan, N. PENGGUNAAN MEDIA GAMBAR DALAM PEMBELAJARAN PKn DI SEKOLAH DASAR. 250-253 (2017).

Wondal, R. Pengaruh Media Pembelajaran Computer Assisted Instruction (Cai) Terhadap Hasil Belajar Siswa. Bioedukasi Univ. Khairun 3, 360-366 (2015). 